$$
M L-70-X X-22
$$

\title{
URBAN DESIGN AND PUBLIC EXPOSURE TO CARBON MONOXIDE
}

\section{ENVIRONMENTAL POLLUTANTS and the URBAN ECONOMY}

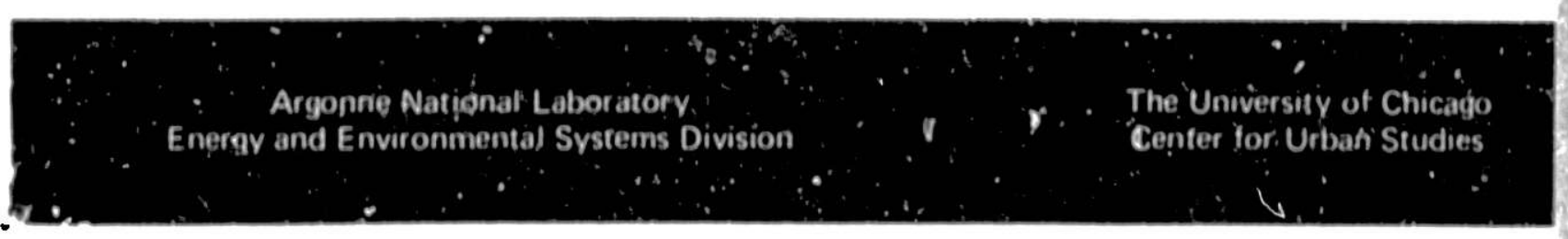

\section{MASTr?}


ANL-76-XX-22

\section{URBAN DESIGN AND PUBLIC EXPOSURE TO CARBON MONOXIDE}

Danilo J. Santini

Argonne National Laboratory

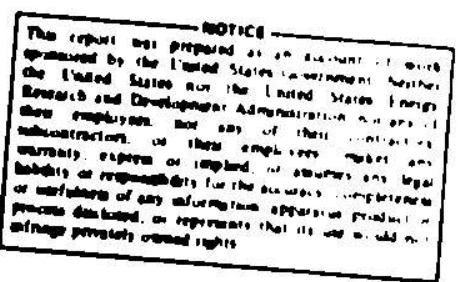

October 1976

\section{ENVIRONMENTAL POLLUTANTS and the URBAN ECONOMY}

Argonne National Laboratory

E.nengy and Environmental Systems Division
The University of Chicago

Center for Urban Studies

\section{MASTRT}

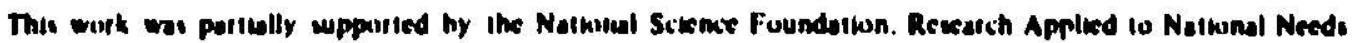

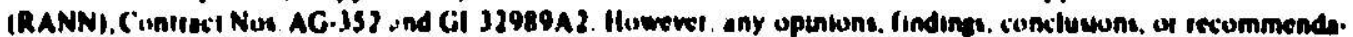

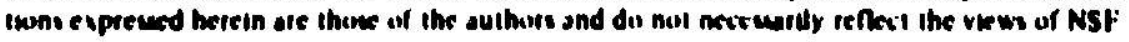


CONTENTS

INTRODUCTION

LOCATIONS WITH THE HIGHEST CO CONCENTRATIONS . . . . 5

LOCATIONS REQUIRING PROTECTION OF THE PUBLIC

METHODS OF REDUCING EXPOSURE RISK . . .

USE OF PHYSICAL DESIGN TO REDUCE FXPOSURE RISK . . . . 8

TYPICAL BUILDINGS IN AREAS OF HIGH CO CONCENTRATIONS 9

FACTORS AFFECTING COSTS AND BENEFITS .

POLICY IMPLICATIONS . . . . . . . . . . . 



\section{URBAN IIISIC;N AND PUBLIC LXPOSURE TO CARBON MONOXIDE}

\section{Inirunlue IIr!l!}

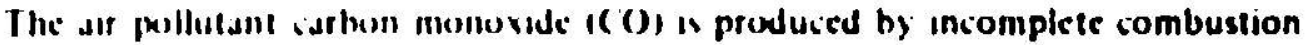

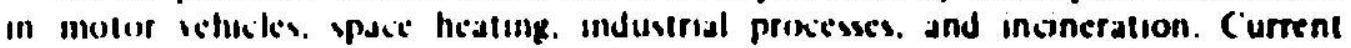
rescarch indwates that lugher derlsity ievdential developments. becauce the kead to ceduced demand lor fuck for home healing and transportation. Iend to lower tatal carbon monoxide cmissions. Howevel, It is in these same areas that concentrations of $\mathrm{CO}$ are the lughest beculux of the denstly of emitters. Since carbon monoxide standards specify maximum allowable concentrations rather than emissions, they tend to deter further development in lucstions where concentrations are already

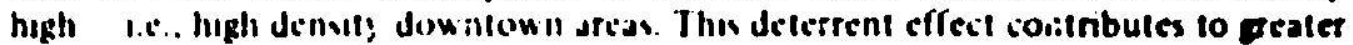
total emissoms of arbon monovide : hence. 11 may be destable to devise a means of controlling the pubise risk of exposure to high CO levels in downtown areas without detcrring new center cills residential development

In proteiting ilue puthlic from the risk of coposure to damaging levels of carbon monovide. two approdihes are possible: the pollutant's concentration may be lowered by tratlic management measures of the public 's rate of exposure may be reduced through urban deven listures. The prexent emphass on traffic management seresses improving the How and reducing the level of traffic - gosls that ane exiremily costly to dihieve in downtown ateas. This paper examines ways to reduce risk of exposure hy the phy visl desgn of new downtown reudental developments. The concept is mol a novel or's. having been sucicessfully implemented in industn' to provide vicupational health alld wicll.

In order to use phystid dewgll to protect the public from exposure to excesave carbon monovide levicls. an arihitect or planner needs to be able to answer the following yuestions

- Whert on a spicilic slle will CO concentrations be the haghest?

- At what is perouf locidiens should the publici he prote: led?

- What dessgen alteritalisces afe adailatile lo provide this protection?

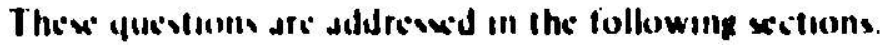

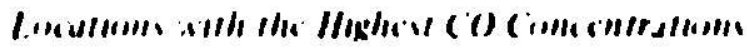

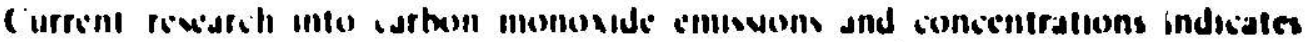

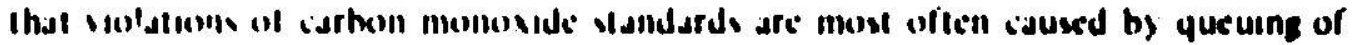

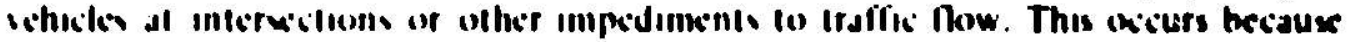

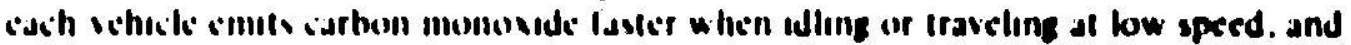

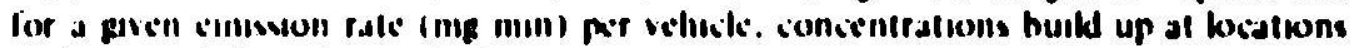

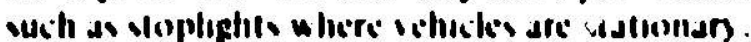

Higher (O) levels alwi diciur when the pollutent is Irspped in troughs of tunnels where mormal wind currents calliner disperue it In a New Yisek Cils sleds. examples were lound whirc decep cut hithwass, urban canjons, tunnels. and aif rights

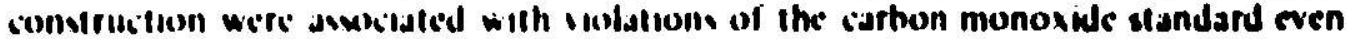




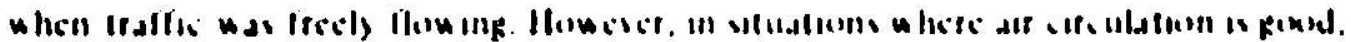

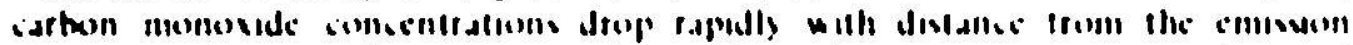

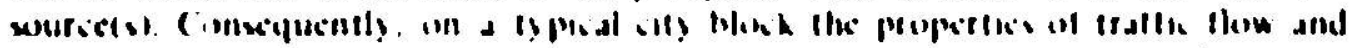

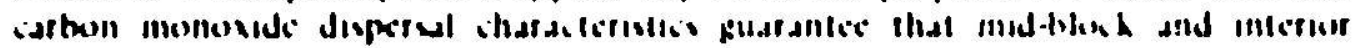

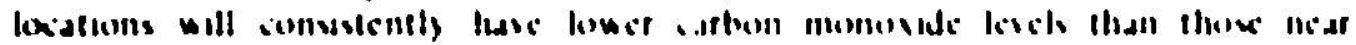
interwitums.

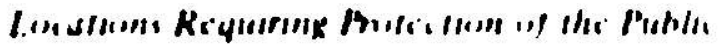

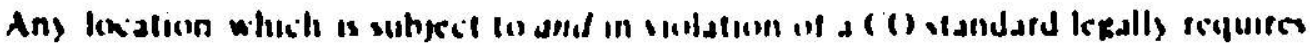

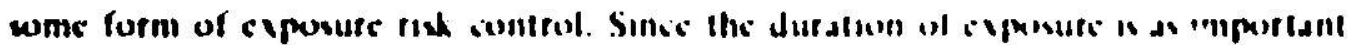

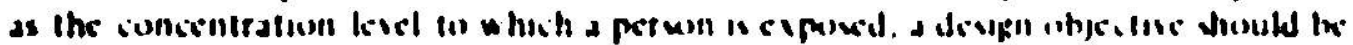

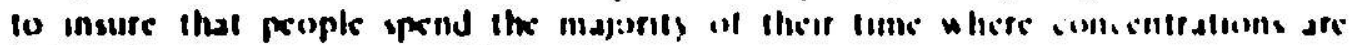
heluw the matimum acieptable level.

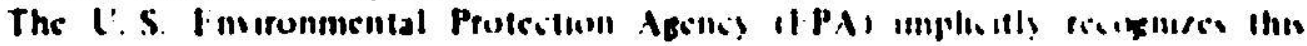

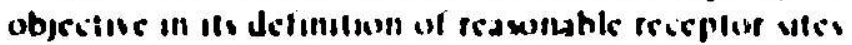

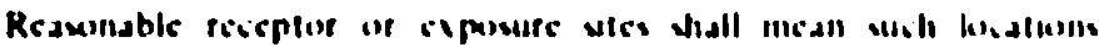

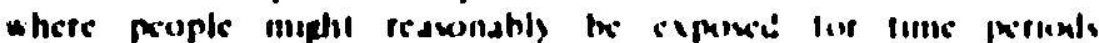

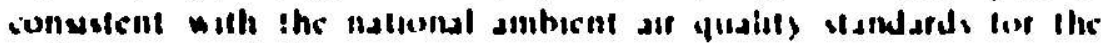
pullutant spcified.

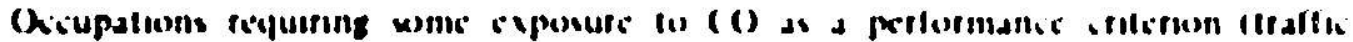

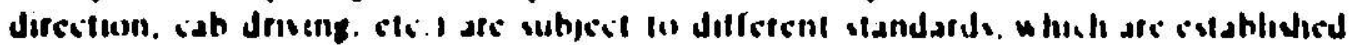
by the Oicupational Sifels alid Health Ait (OSIIA)

Most receptur stles whih afe dertned untedunable afi placts a hefe prople mipht

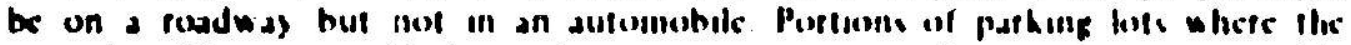

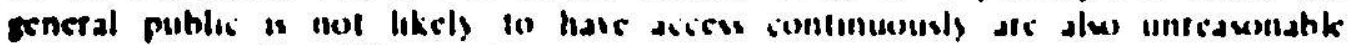

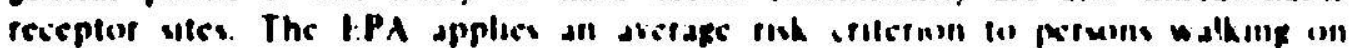

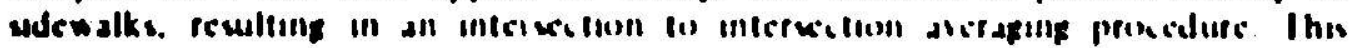

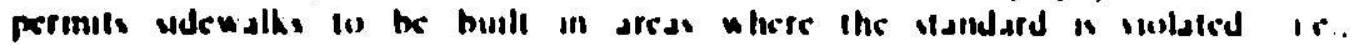

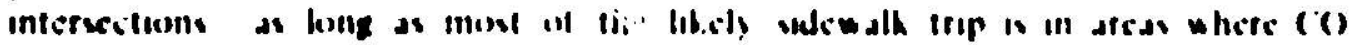
cuncentraluens afc diceptabls lim

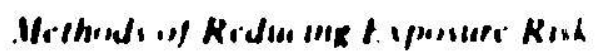

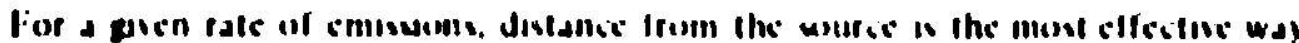

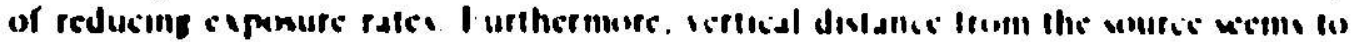

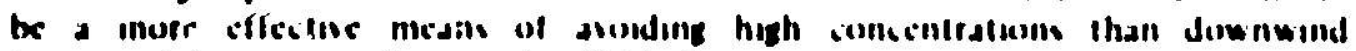
hopiontal distance. do illustedlcd on Iable I

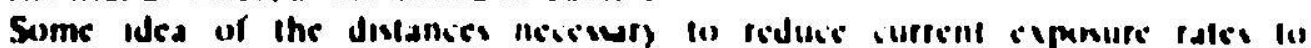

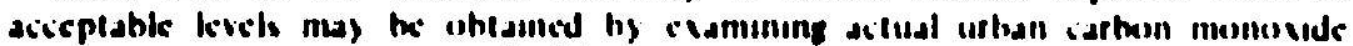
concentrafiuns. During the 1474.75 monituring yeaf for the (it) of (hicial, th:

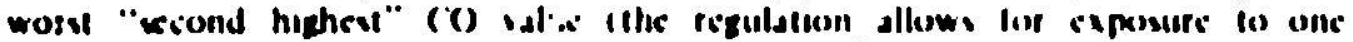

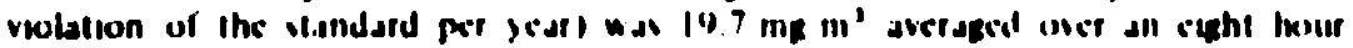

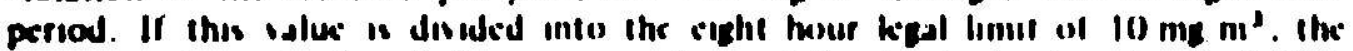
concentration reduction factor neccesan to meet the slandard is found to be 0.50 ?.

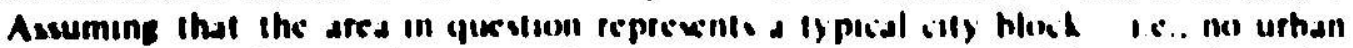

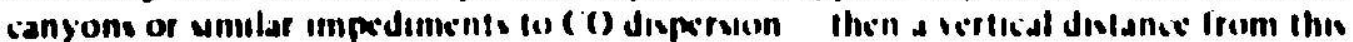

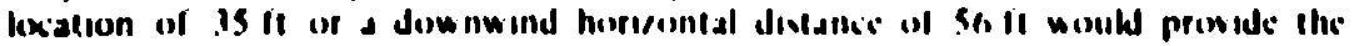




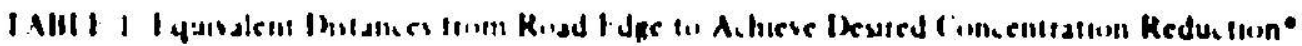

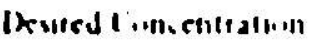

Reduclion I ding

Virtinal Inarariar

bromest (fl)

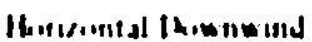

Ihslather Vocoriuls (II)
$11+1$

11

$+$
() it

$115 ?$

() +t

0.18

$0.2 ?$

$\therefore$

(1)

t)

so

$\infty$

$$
\text { -..... }
$$

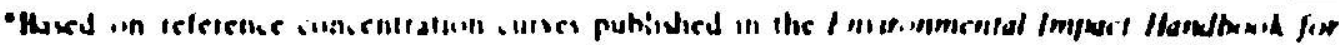

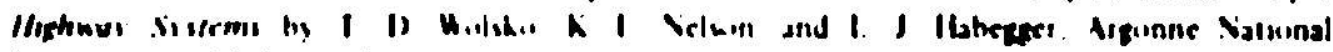

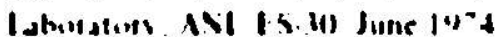

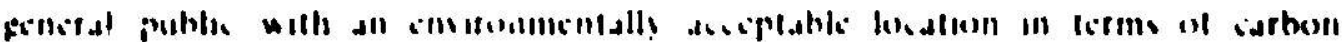

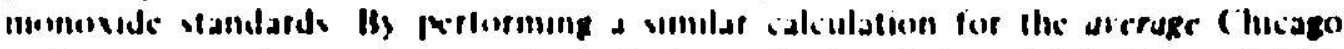

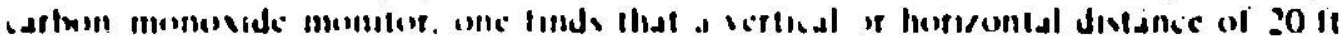

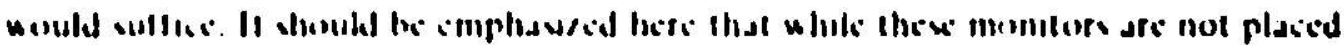

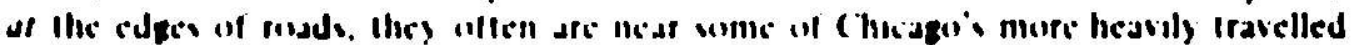

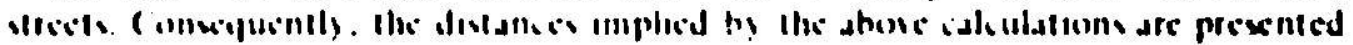
for illualestive purpene anls

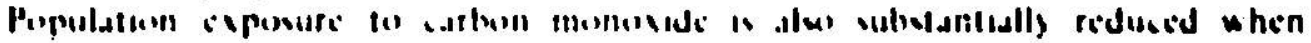

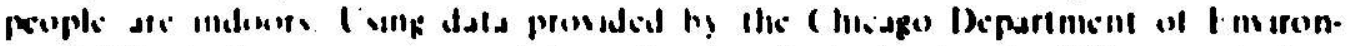

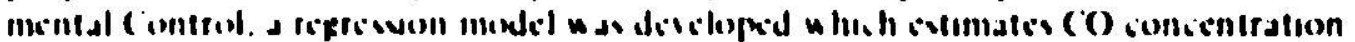

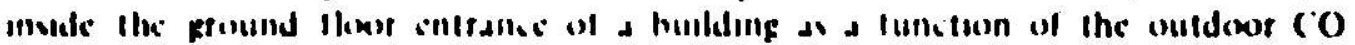

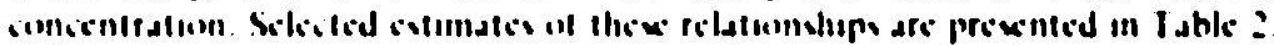

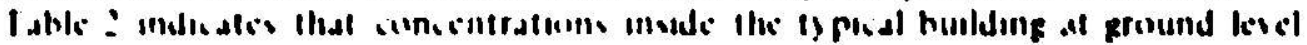

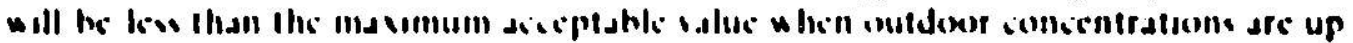

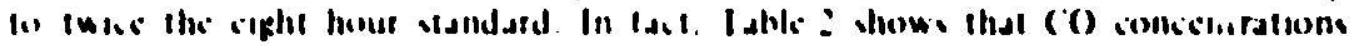

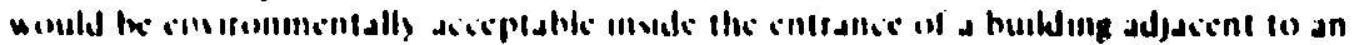

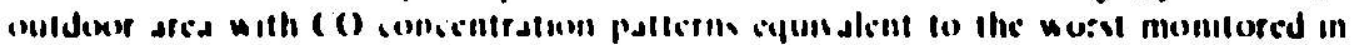

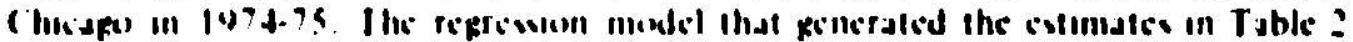

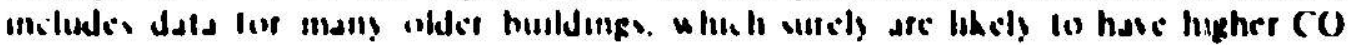

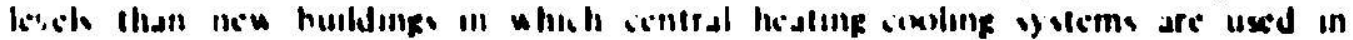

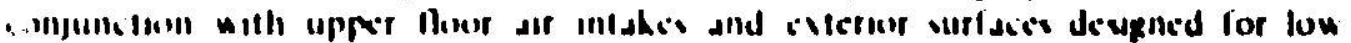

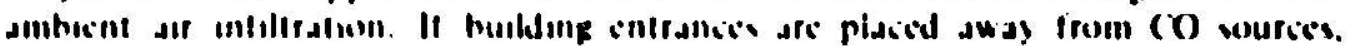

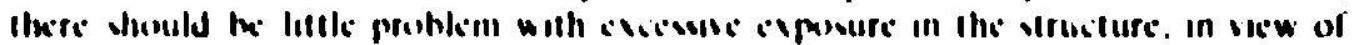

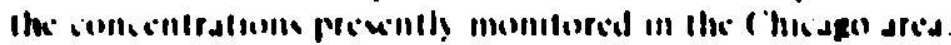

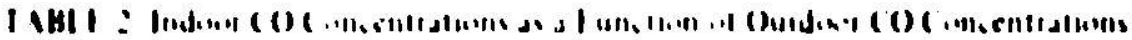

Ourdinie (c)

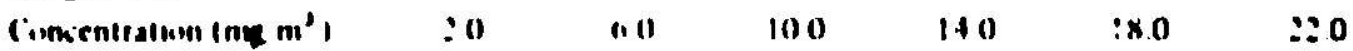

Psimuled Indenis (c)

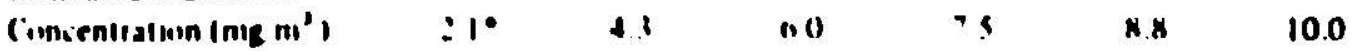

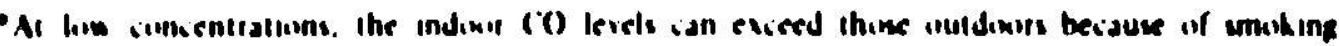
and in luel , cullohusion lew he line 


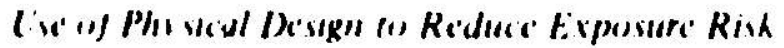

It is apparent Irom the I:PA definttion of reasonable receptors described tarlier

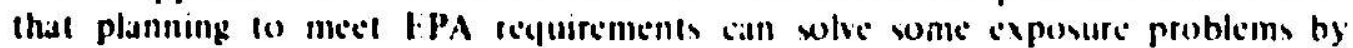
manpulating the relationships betereen outdoor public space and patial variation in C $O$ concintrations.

For example. slthough isdewalks are traditionally construcled next to roadways. this certalily is not necessury. If they were to be moved away from roads in general and intersections in particular. the exposure rates of pedestrians would be reduced. It is possible to design sudewalks that will reduce the time of exposure at an intersection b; the use of geometrical properties. At a uniformly congested intersection with random wind patlerns, sidewalks criented at $45^{\circ}$ from the roadwass minimize pedestrian CO exposure near the interection. Away from the streets. sidewalks might resume a direction paralkel to that of the roads. Given different relative congestion and wizd directions. the optimum angle for the sidewalks would vary. Two sidewalk design options are illustrated in Fig. I.

Another use of the sidewalks is for public iransit stops at intersections, which are desirable from an operational standpoint since buses have to stop at intersections anyway. However. environmentally. a mid-block iransit stop. out of the: moving lanes of traffic, is more desirable when infersections are particularly bad.

A possibly unat:ractive way to prevent the public from using open spactes that are likely to have high levels of $\mathrm{CO}$ is to place fences around those areas. Mon: aesthetically pleasing solutions. especially for a boundary hetween roads and residential developments. may be to (l) plant the area with appropriate shrubbery or (2) build earthen mounds covered with planting. The earthen mound design alternative can also reduce ground level noise within the area and provide a more pleasing ground level view for peisons looking toward th: stree:.

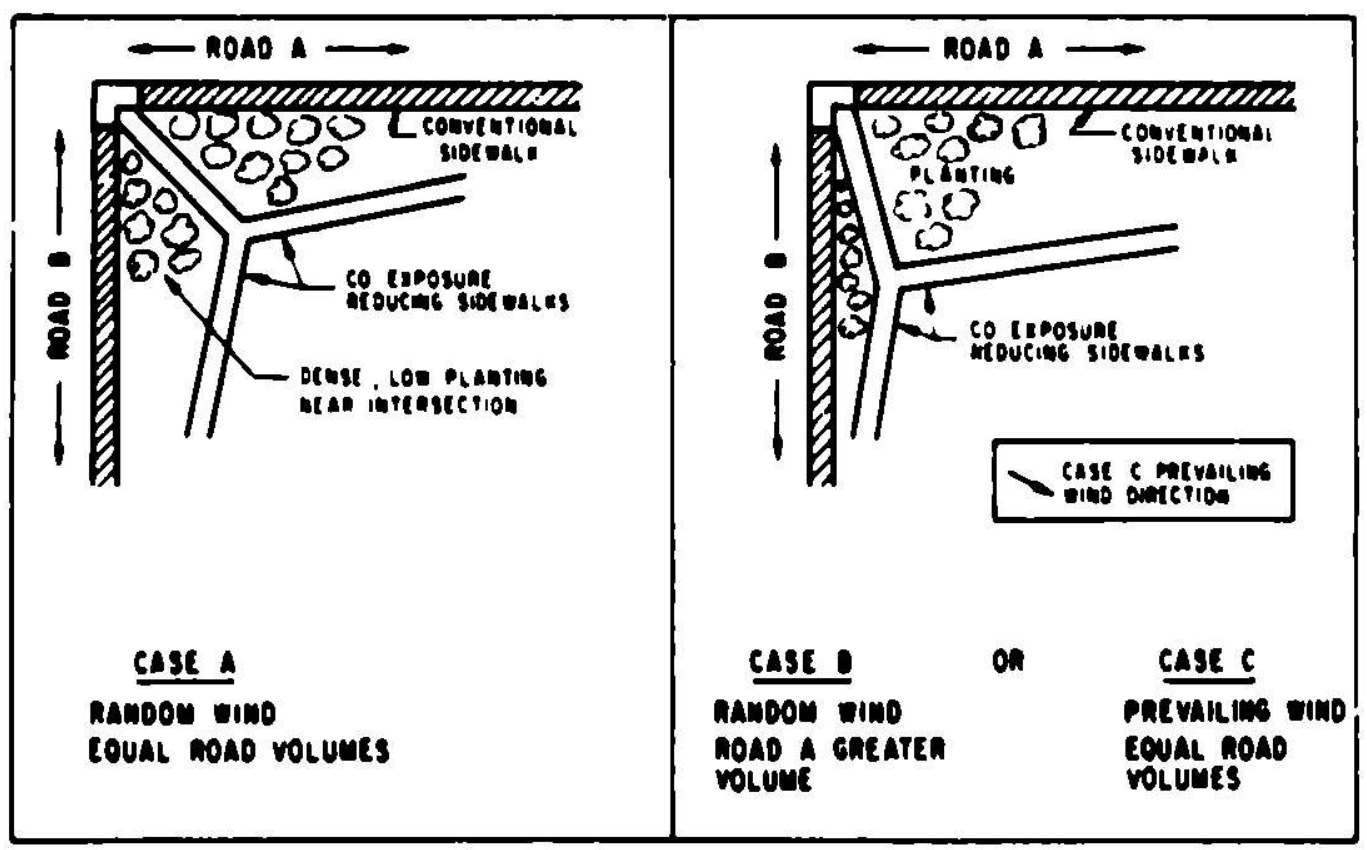

Fig 1. COtexposure Reducing Sidewalh Design 
lentes can present bort-cul medestrian routes deross ground level parking lots.

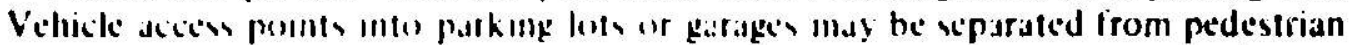

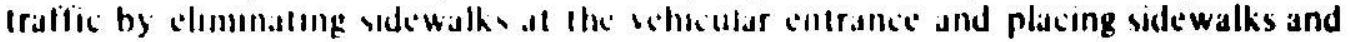
pedestrian entrances at edgen of the parking licilit! which are removed from the strect. Within ihe parking lacility licelf pidentran how should be xeparate from vehicular tlow. and the pedestriar? and rehloular entrances and exits should be distenct. with velucular powgers desgled to discourage pedestriall us:

The parking lot entrantic or ever. unce 11 1 a locallon where a queue of automubiles mas build up. is cquasateme to an mlersectlon. A park ang facility serving a particular bulling will hase peak parking volume at the same time is peak pedestrian volume. ville mant pedevtruall ciltrante to a bulding are merely people who recently latt their parked cars. Ilecrelore, when parking facdities serve a

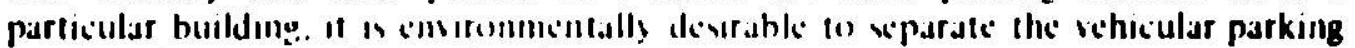
entrance from the pedistrian bunldeng cilltronce.

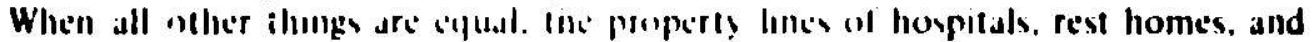
playgrounds should be lurther rellowed Irom aress of high 60 concentration than

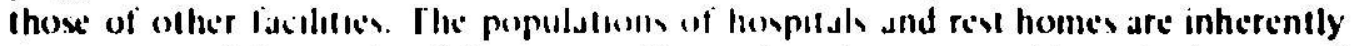
more susciptible io the deletertous afficts of esrbon monoxide and playground excrcix increase children's uplake of (c).

Other suggestloms an be made with revpest to stret and huilding contiguration and parking lacility location. Firs. whell internat rosd are placed at the outside

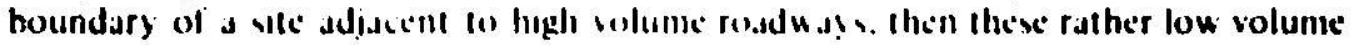

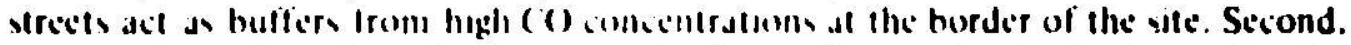
construction of parking lacilites in the lower flowe of a high rise residential

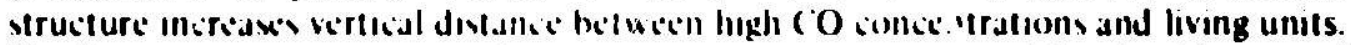
Finally. parking garages placid at inlictection prevent ground level public uxe of such locations: public recreatlonal lasilitse on the root of the type of parking garage would be one way of mantaming devred itivironmentally accieptable public spact.

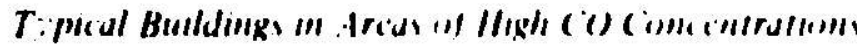

Carbon monoxide in likidy to he a problem in arciss clox to high volume. stop and go Iraffic: Further, the evera traffic crealed by commercial and business activity generaliy leads to higher sarhon monovide levels. Usually sites with such characteristlis will be lor.aled near the husiness core of a city or town. where net residential densitles ment often are connderably higher than in a city's purely residential areas. Th: 1s me of restential building commonly found in such environments 1.6. t.le multi-lloor mad-and high-rix bulding is desirable from the point of view of reducing $(C)$ sposure.

Multi-story living in the vicinity of healy irafitic volunie has several virtues. First. upper story dwelling units themselves have the advantage of vertical distance from the source of pollution which. w mentiomed. is even more elfective than horizontal distancte. Second, in upper lloor dwelling units. residents do not use the air space immediately adjacie I to the unit for recreattomal purposes. Third. in multi-story buildings, it is possible (and common) to instalt air intakes for the buidding at upper levels for central headting and/or air conditioning. Finally. The entrance of a multi-story huilding may be designed to he a reasonjable distance from sources of carbon monoxide. These desirsble properties of mulfi-story buildings exist only when land coverage by huildings is nol completc. If multe-story buildings are used at 


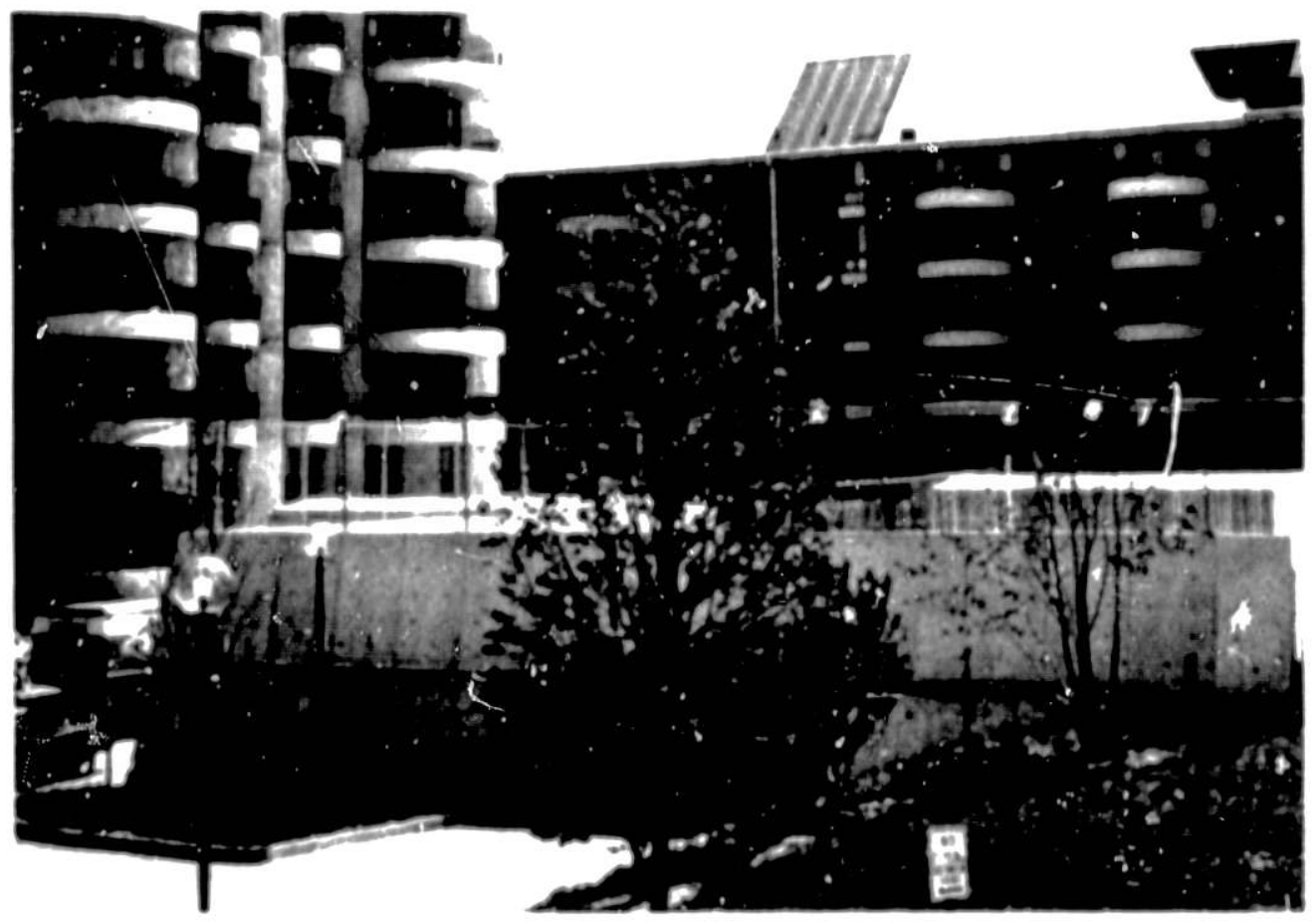

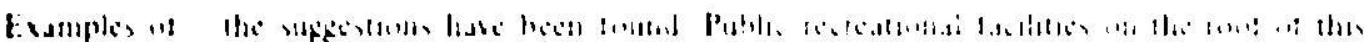

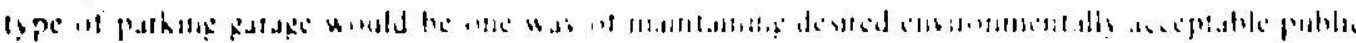
pd.:

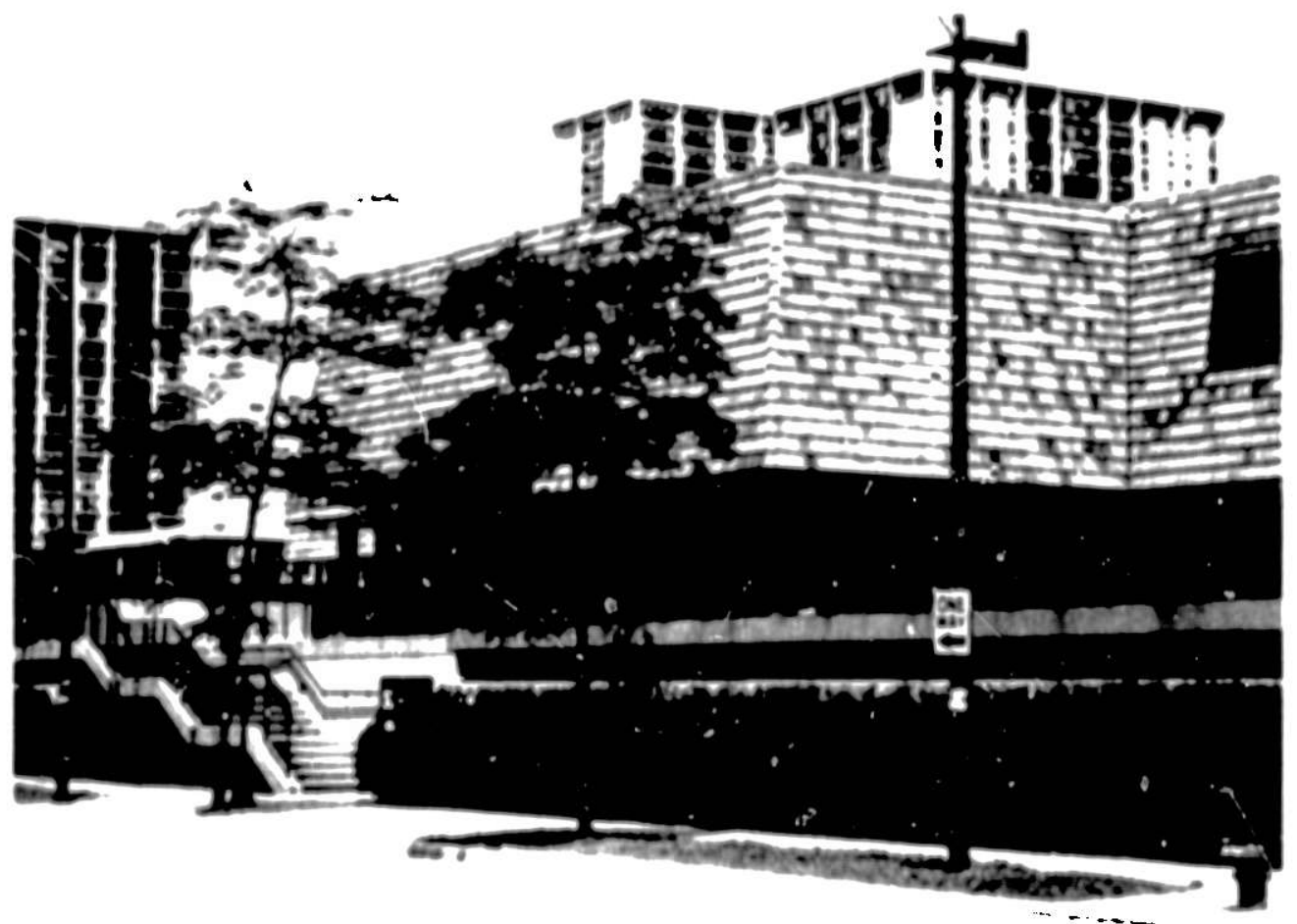


all locations along a rojdway. these virlues are climinated hecause an urban canyon ellect 1 ircisted ill whish carhon monoside emessons ale trapped. Reasonably

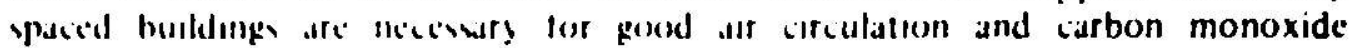
desperal

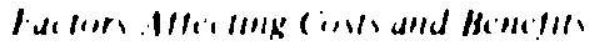

Ihw paper has wagested that plyysuldesign can be employed to protect the puble from corbon inomovede concentrattems in the case of residential developments dese lo ligh bolums. vop and go tralfle. An important question is whether the

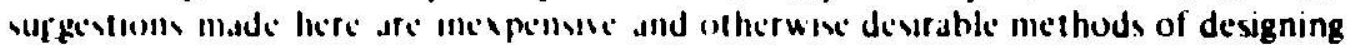
wich revdentlal derclopments. The question is best answered on an individual desclopment-by-deschepmesth bast. Howerer. the suggestlons made heje do not

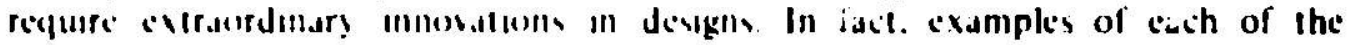

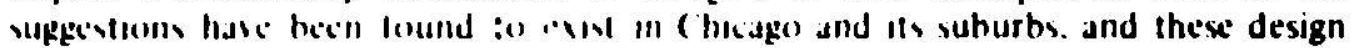
alternative dad not arix from comsderatiom of carbon monoxide concentrations.

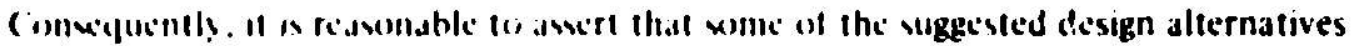
are likely lo gecur in a dountoun lotty or vuburbanl development even if exposure (1) carbon momonde is mot comsdered. Whitere ligh-risc or mid-rise buildings and

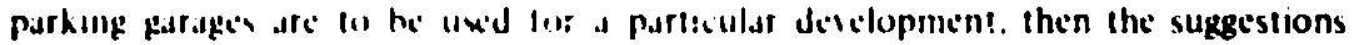

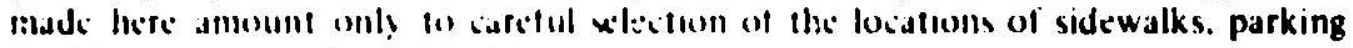

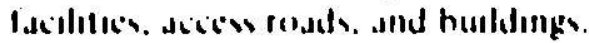

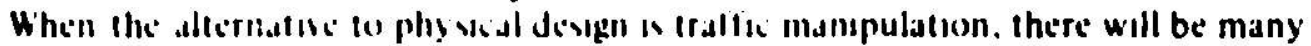
case ill whish ph! vid devg"l will be the more ciconomial means of lowering public

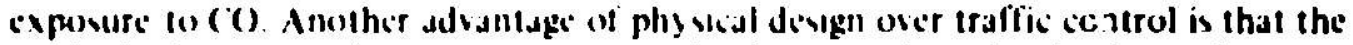
method of mectumg ihe objectere a completely mernal so the developer. It is not

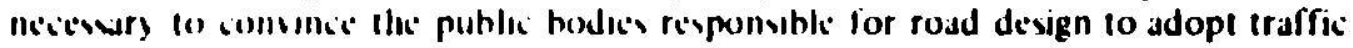
collirol medsures that will atfect more persoms outside the sle than within. Even wher iralfic control 1 a cost-teneficial welutien on theoretleal grounds. it may be diffic:lt to operationally effect the iransler of benefits from ihe residents of the site to the drivers alld pascingers who pass by the vite or who aft forced to take an allernativic route

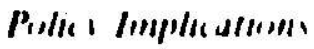

Thw discuwen has comicrmed a megleited and potentially costeffective approach for comply ille with carhon monoside alr yuality regulations. The disciussion here has heen neciesurily hriel. alld lisls sloort of providing all the knowledge needed for the vite plathiter of arihilict to deite when the teihniques suggested are useful and to what evlent thes could be applied. It the approach suggested here were to be acicepted as a complement to (C) comissoms reduction through locial traffic contiol. then desgn handhexok, could readily be developed for use by the professional design communuty. 
For further information on the study described in this report. please contact:

Dr. A. S. Cohen

Argonne National Laboraton

Energy and Environmental Systems Division 9700 South Cass Avenuc

Argonne, Illinois 10439

or

Prot. G. S. Tolley

The L'niversity of Chicago

Department of F.conomics

1126 East 59th Street

Chicago. Illinois 60637 